\title{
Upaya Meningkatkan Kemampuan Menulis Puisi Dengan Menggunakan Media Gambar Siswa Kelas VI SD Negeri No. 101/II Muara Bungo Kecamatan Pasar Muara Bungo Kabupaten Bungo
}

\author{
Sarniwati \\ Sekolah Dasar Negeri No. 101/II Muara Bungo Kecamatan Pasar \\ Muara Bungo Kabupaten Bungo \\ sarniwati@yahoo.com
}

\begin{abstract}
Abstrak
Tujuan penelitian ini adalah untuk mengetahui sejauh mana keberhasilan menggunakan media pembelajaran gambar dengan memperhatikan ada atau tidaknya peningkatan kemampuan menulis puisi siswa kelas VI SD Negeri No. 101/II Muara Bungo. Metode penelitian yang dipergunakan adalah Penelitian Tindakan Kelas (PTK). Penelitian Tindakan Kelas (PTK) merupakan salah satu pendekatan dalam penelitian yang berbasis kelas atau sekolah untuk melakukan pemecahan berbagai permasalahan yang digunakan dalam rangka peningkatan kualitas pendidikan. Hasil penelitan, diperoleh hasil bahwa pertama, pada dasarnya para peserta didik kelas VI mampu untuk membuat suatu puisi sederhana, hanya saja diperlukan media yang dapat merangsang imajinasi mereka. Kedua, media gambar ternyata dapat digunakan untuk merangsang imajinasi para peserta didik kelas VI, sehingga pada akhirnya mereka dapat membuat satu bait puisi.
\end{abstract}

Kata Kunci: menuli, puisi, media gambar

\begin{abstract}
The purpose of this study is to determine the extent to which the success of using image learning media with regard to whether or not the increase in the ability to write class poetry students VI SD Negeri No. 101/II Muara Bungo. The research method used is Classroom Action Research. Classroom Action Research (PTK) is one approach in classroom or school-based research to solve various problems used in the context of improving the quality of education. The results of research, obtained the results that first, basically the students of class VI able to make a simple poem, it's just necessary media that can stimulate their imagination. Secondly, the media images can be used to stimulate the imagin
\end{abstract}

Keywords: poetry, writing, image media 


\section{PENDAHULUAN}

Puisi merupakan salah satu wujud penyampaian gagasan dan pikiran seseorang yang dituangkan dalam bentuk suatu karya seni sastra. Untuk menghasilkan puisi yang baik perlu suatu latihan untuk mengasah kemampuan mereka untuk membentuk kalimat-kalimat yang memiliki keindahan yang dapat ditangkap oleh indra perasaan pembacanya. Kemampuan itu tak akan bisa muncul bila seseorang tidak memiliki kemampuan membuat kalimat dengan baik. Membuat kalimat yang komunikatif, baik secara lisan maupun tulisan, harus sudah dikuasai oleh seseorang agar mampu menyampaikan gagasannya kepada orang lain. Gagasan-gagasan yang dimiliki dan ingin disampaikan kepada pihak lain harus mampu direspon dengan baik oleh orang lain. Oleh karena itu sejak dini anak-anak diarahkan agar mampu menggunakan bahasa Indonesia dengan baik dan benar untuk berkomunikasi dalam berbagai situasi yaitu mampu menyapa, mengajukan pertanyaan, menjawab, menyebutkan pendapat dan perasaan melalui bahasa (Thahir, 1993:2).

Dasar pembelajaran bahasa Indonesia adalah pembelajaran keterampilan berbahasa yaitu keterampilan-keterampilan yang ditekankan pada keterampilan reseptif, dan keterampilan produktif. Pembelajaran bahasa Indonesia Sekolah Dasar kelas I diawali dengan pembelajaran reseptif. Dengan demikian keterampilan produktif dapat ikut di tingkatkan. Empat aspek keterampilan berbahasa yang mencakup dalam pengajaran bahasa adalah: keterampilan menyimak (listenin skils), keterampilan berbicara (speaking skills), keterampilan membaca (reading skills), keterampilan menulis (writting skills), (Tarigan, dalam Muchlisoh, 1996:257).

Keempat keterampilan berbahasa diatas merupakan satu kesatuan yang tidak dapat dipisahkan satu sama lain, tetapi hanya dapat dibedakan. Keterampilan yang satu bergantung dengan keterampilan yang lain. Siswa diharapkan memiliki keterampilan berbahasa yang lengkap. Tidak dapat dikatakan siswa mampu berbahasa yang baik dan benar, bila mereka hanya terampil menyimak, berbicara dan membaca tetapi tidak terampil menulis. Jadi keterampilan menulis harus benar-benar diperhatikan karena terutama di Sekolah Dasar, karena dengan cara 
itu guru dapat menjadikan siswa memiliki kemauan berbahasa Indonesia yang baik dan benar.

Berdasarkan pengalaman selama mengajar, kemampuan menulis siswa kelas VI di SD Negeri No. 101/II Muara Bungo relatif rendah. Hal ini disebabkan oleh beberapa faktor, antara lain kurangnya dukungan orang tua terhadap cara belajar peserta didik, latar belakang orang tua yang berpendidikan rendah, bahkan banyak yang tidak memperoleh pendidikan formal, kesalahan metode pengajaran yang dilakukan oleh guru dalam menyampaikan materi pelajaran menulis kepada para peserta didik Melalui media gambar diharapkan siswa kelas VI dapat membuat kalimat-kalimat apresiatif tentang gambar tersebut, sehingga akan lebih mudah bagi siswa untuk membuat suatu puisi. Dengan membagikan gambargambar, baik berupa pemandangan maupun bentuk-bentuk lainnya, setiap siswa diharapkan untuk memiliki suatu imajinasi tentang gambar tersebut. Imajinasi tersebut dituangkan ke dalam bentuk tulisan. Pada awalnya mereka akan membuat kalimat yang sederhana, seperti "pemandangan yang indah" manakala seorang siswa mengamati gambar pemandangan.

Secara umum tujuan penelitian ini adalah untuk mengetahui sejauh mana keberhasilan menggunakan media pembelajaran gambar dengan memperhatikan ada atau tidaknya peningkatan kemampuan menulis puisi siswa kelas VI SD Negeri No. 101/II Muara Bungo.

\section{METODE PENELITIAN}

Berdasarkan rumusan masalah dan tujuan penelitian ini, maka rancangan penelitian yang dipergunakan adalah Penelitian Tindakan Kelas (PTK). Penelitian Tindakan Kelas (PTK) merupakan salah satu pendekatan dalam penelitian yang berbasis kelas atau sekolah untuk melakukan pemecahan berbagai permasalahan yang digunakan dalam rangka peningkatan kualitas pendidikan (Tim Pelatih Proyek PGSM, 1999:1-2). Menurut Sukarnyana (2002:11), Penelitian Tindakan Kelas (PTK) merupakan salah satu cara yang strategis bagi guru untuk meningkatkan layanan pendidikan melalui penyempurnaan praktik pembelajaran di kelas. 
Penelitian Tindakan Kelas (PTK) ini menggunakan model kolaborasi yang mengutamakan kerjasama antara kepala sekolah, guru dan peneliti. Penelitian Tindakan Kelas (PTK) ini merupakan upaya untuk mengkaji apa yang terjadi dan telah dihasilkan atau belum tuntas pada langkah upaya sebelumnya. Hasil refleksi digunakan untuk mengambil langkah lebih lanjut dalam upaya mencapai tujuan penelitian. Dengan kata lain refleksi merupakan pengkajian terhadap keberhasilan atau kegagalan terhadap pencapaian tujuan tindakan pembelajaran.

Pada dasarnya Penelitian Tindakan Kelas (PTK) memiliki karakteristik yaitu: (1) bersifat situasional, artinya mencoba mendiagnosis masalah dalam konteks tertentu, dan berupaya menyelesaikannya dalam konteks itu; (2) adanya kolaborasi-partisipatoris; (3) self-evaluative, yaitu modifikasi-modifikasi yang dilakukan secara kontinyu - dievaluasi dalam situasi yang terus berjalan secara siklus, dengan tujuan adanya peningkatan dalam praktek nyatanya.

\section{HASIL DAN PEMBAHASAN}

Observasi awal dilakukan peneliti pada kelas VI, jam 1-2 . Peneliti melakukannya tanpa menggunakan media presentasi pembelajaran. Hal ini cukup dilakukan di dalam kelas. Tindakan yang dilakukan peneliti adalah (1) Memberikan apersepsi tentang cara membuat puisi yang baik kepada para peserta didik. (2) Membagikan gambar-gambar pemandangan kepada semua peserta didik. (3) Menugasi para peserta didik menuliskan pendapat mereka mengenai gambar pemandangan yang telah mereka terima.

Hasil observasi awal dan evaluasi terhadap objek kelas VI, diperoleh sejumlah kasus, yaitu (1) Ada peserta didik yang tidak mampu mengeluarkan pendapat mereka dalam bentuk tulisan. (2) Ada peserta didik yang idak mampu menulis kalimat dengan baik dan benar se-hingga pendapat yang mereka tulis sulit untuk dimengerti. (3) Ada beberapa peserta didik yang mencontoh pendapat temannya, sehingga pendapat mereka sama.

Dari hasil observasi awal dan evaluasi maka diperlukan rencana tindakan 1 yakni diperlukan penjelasan relatif lebih lama untuk membuat para peserta didik faham maksud penggunaan media gambar tersebut. Agar siswa tidak mengalami 
kesulitan mengungkapkan pendapat mereka tentang gambar yang telah mereka terima, peneliti melakukan beberapa langkah-langkah. Pada Tahap 1 yaitu (1) Penyampaian penjelasan dan beberapa contoh mengungkapkan pendapat selama 10 menit, dilanjutkan tugas menulis sebuah kalimat yang berisikan pendapat mereka selama 5 menit. Tahap 2 yang dilakukan adalah penyampaian penjelasan selama 10 menit dilanjutkan tugas membuat kalimat kedua tentang pendapat mereka selama 5 menit. Tahap 3, setelah menyelesaikan dua kalimat pendapat mereka tentang gambar pemandangan yang mereka tulis, dilanjutkan dengan menulis kalimat ketiga pandapat mereka tentang gambar yang telah mereka terima tersebut selama 5 menit. Tahap keempat dilakukan dengan menugasi para peserta didik untuk menuliskan kalimat keempat pendapat mereka selama 5 menit.

Dalam siklus 1, tindakan yang dilakukan penelitian adalah (1) Melakukan penelitian pada kelas VI. (2) Para siswa menyiapkan alat tulis. (3) Peneliti memberikan pengantar dan penjelasan materi selama 10 menit. (4) Peneliti menerangkan maksud dari gambar-gambar pemandangan tersebut. (5) Setelah selesai memberikan penjelasan tentang gambar-gambar pemandangan tersebut, peneliti menugasi para peserta didik selama menit menuliskan pandapat mereka tentang gambar-gambar yang telah mereka terima dari peneliti perkalimat hingga terbentuk empat kalimat pendapat dengan masa penulisan masing-masing kalimat selama 5 menit. (6) Peneliti mengumpulkan hasil tulisan siswa dan menutup pertemuan tersebut.

Hasil Observasi 1 menunjukkan bahwa siswa antusias sekali saat menyaksikan gambar-gambar yang diberikan peneliti dan memperhatikan penjelasan peneliti dengan seksama. Pada saat ditugasi menulis pendapat mereka tentang gambar yang telah mereka terima mereka masih bingung atas pengungkapan pendapat mereka secara tertulis. Hal ini menunjukkan mereka masih perlu bimbingan dalam menuliskan pendapat.

Hasil dari Refleksi 1 yakni siswa antusias sekali saat menyaksikan gambar-gambar yang diberikan peneliti dan memperhatikan penjelasan peneliti dengan seksama. Pada saat ditugasi menulis pendapat mereka tentang gambar 
yang telah mereka terima, beberapa siswa menunjukkan kebingungannya karena harus mengingat ingat apa yang telah disimak sebelumnya, hal ini menunjukkan mereka masih memrlukan bantuan dalam mengungkapkan pikiran mereka mengenai gambar yang dilihatnya. Beberapa kesalahan baik struktur bahasanya maupun ejaannya pada beberapa anak.

Berdasarkah hasil observasi peneliti pada tabel 1 diketahui bahwa, pada siklus 1 diketahui para peserta didik kelas VI ralitif cukup baik dalam melaksanakan tugas yang diberikan oleh peneliti, meskipun ada sebagian yang masih bingung dalam mengerjakannya. Hal ini terlihat pada data yang termuat dalam lembar observasi, yaitu 13 peserta didik yang cukup baik dalam melaksanakan tugas, yang artinya $46 \%$ baik dari seluruh peserta didik di kelas VI, sedangkan pada kemampuan mengerjakan tugas pada siklus I diketahui sebagian besar para peserta didik di kelas VI SD Negeri No. 101/II Muara Bungo Kec. Pasar Muara Bungo Kab. Bungo Provinsi Jambi belum mampu membuat puisi.

Tabel 1. Aktivitas dan hasil Belajar Siswa Pada siklus I

\begin{tabular}{|c|c|c|c|}
\hline No. & Nama siswa & Aktivitas siswa & Hasil pengerjaan tugas \\
\hline 1 & AHMAD AFANDI & 12 & 8 \\
\hline 2 & AYU MARLINDA & 12 & 8 \\
\hline 3 & FITRA BAYU KRISTANTO & 11 & 5 \\
\hline 4 & JULIO PRASETYO & 9 & 7 \\
\hline 5 & KELVIN RENOL PERMANA & 6 & \\
\hline 6 & LUH DHENOK BANUWATI & 11 & 8 \\
\hline 7 & LUSI OKTAVIANI WENNO & 6 & 6 \\
\hline 8 & MUHAMMAD TIO & 9 & 5 \\
\hline 9 & MOHAMMAD ANGGA & 11 & 6 \\
\hline 10 & RIMA QORIA WATI & 9 & 12 \\
\hline 11 & RILA SUNDARI & 7 & 8 \\
\hline 12 & RIZKY SADONA A & 9 & 5 \\
\hline 13 & RIZKY SANTOSO & 7 & 7 \\
\hline 14 & SANTI PRASTIWI & 7 & 12 \\
\hline 15 & TRY NURJANAH & 11 & 8 \\
\hline 16 & WIDYANOVITANIA & 9 & 7 \\
\hline 17 & WAHYU SETIAWAN & 4 & 6 \\
\hline 18 & MUHAMAD MANSUR M & 4 & 6 \\
\hline 19 & RIZKI ANTIKA NINGRUM & 9 & 6 \\
\hline 20 & FADILAH SARASUNI & 7 & 6 \\
\hline 21 & ALVIOLA DWI ARIFIN & 11 & 6 \\
\hline 22 & MEYSI RATNA INDARTI & 7 & 8 \\
\hline 23 & ANDRE JUNAIDY P & 8 & 7 \\
\hline 24 & LEVIA TAMYIZ & 6 & 6 \\
\hline
\end{tabular}




\begin{tabular}{r|l|c|c}
\hline No. & \multicolumn{1}{|c|}{ Nama siswa } & Aktivitas siswa & Hasil pengerjaan tugas \\
\hline 25 & SYAIFANI AMALIA & 8 & 6 \\
\hline 26 & YOKEBETH ALFA & 6 & 7 \\
\hline 27 & NUR ALDI F & 10 & 5 \\
\hline 28 & ARDIYANSAH & 10 & 5 \\
\hline
\end{tabular}

Rencana Tindakan 2 yakni diperlukan penjelasan relatif lebih lama untuk membuat para peserta didik faham maksud penggunaan media gambar tersebut. Agar siswa tidak mengalami kesulitan mengungkapkan pendapat mereka tentang gambar yang telah mereka terima tersebut peneliti melakukan beberapa langkah. Tahap 1 : Penyampaian penjelasan dan beberapa contoh mengungkapkan pendapat selama 10 menit. Dilanjutkan tugas menulis sebuah kalimat yang berisikan pendapat mereka selama 5 menit. Tahap 2 : Penyampaian penjelasan selama 10 menit. Dilanjutkan tugas membuat kalimat kedua tentang pendapat mereka selama 5 menit. Tahap 3 : Setelah menyelesaikan dua kalimat pendapat mereka tentang gambar pemandangan yang mereka tulis, dilanjutkan dengan menulis kalimat ketiga pandapat mereka tentang gambar yang telah mereka terima tersebut selama 5 menit. Menugasi para peserta didik untuk menuliskan kalimat keempat pendapat mereka selama 5 menit.

Pelaksanaan tindakan 2 atau sikulus 2. Dalam siklus 2, tindakan yang dilakukan penelitian adalah (1) Melakukan penelitian pada kelas VI A. (2) Peneliti membagikan gambar-gambar pemandangan kepada para peserta didik, dan setiap anak memperoleh gambar yang berbeda dari yang mereka terima pada siklus 1 . (3) Peneliti memberikan pengantar dan penjelasan materi selama 10 menit. (4) Peneliti menerangkan maksud dari gambar-gambar pemandangan tersebut. (5) Setelah selesai memberikan penjelasan tentang gambar-gambar pemandangan tersebut, peneliti menugasi para peserta didik selama menit menuliskan pandapat mereka tentang gambar-gambar yang telah mereka terima dari peneliti perkalimat hingga terbentuk empat kalimat pendapat dengan masa penulisan masing-masing kalimat selama 5 menit. (6) Peneliti mengumpulkan hasil tulisan siswa dan menutup pertemuan tersebut.

Hasil Observasi 2 menunjukkan Peserta didik cukup antusias dalam mengikuti pembelajaran cara membuat puisi dengan media gambar. Para peserta 
didik sudah mampu menuliskan pendapat mereka dengan baik. Keempat kalimat yang telah dibuat oleh masing-masing peserta didik bila dirangkai telah menjadi sebuah bait puisi.

Hasil Refleksi 2 menunjukkan bahwa siswa antusias sekali saat menyaksikan gambar-gambar yang diberikan peneliti dan memperhatikan penjelasan peneliti dengan seksama. Pada saat ditugasi menulis pendapat mereka tentang gambar yang telah mereka terima, peserta didik telah mampu melaksanakan tugas yang diberikan oleh peneliti, hal ini menunjukkan adanya peningkatan kemampuan para peserta didik kelas VI A dalam mengungkapkan pendapat yang pada akhirnya membentuk sebuah bait puisi. Ada beberapa sedikit kesalahan baik struktur bahasanya maupun ejaannya pada beberapa anak.

Setelah dilaksanakan proses pengajaran paska siklus 1 kurang lebih 4 kali pertemuan maka perlu diadakan evaluasi siklus 2 untuk mengetahui tingkat keberhasilan penggunaan media pembelajaran gambar sebagai upaya meningkatkan kemampuan para peserta didik di kelas VI dalam membuat puisi. Ternyata ada peningkatan baik dari segi pengerjaan tugas yang diberikan oleh peneliti maupun tingkat kemampuan para peserta didik dalam membuat puisi secara sederhana. Hal ini terlihat dari jumlah para peserta didik yang mampu membuat puisi sedehana lebih tinggi dari pada proses pengajaran siklus 1 .

Lebih dari $90 \%$ dari seluruh peserta didik di kelas VI telah mampu membuat satu bait puisi sederhana tentang pemandangan alam. Seandainya pengajaran ini diteruskan ada kemungkinan mereka lebih mampu membuat puisi dengan baik, dan bahkan apresiasi mereka pada puisi akan jauh lebih baik. Tabel 2. merupakan hasil keterampilan menulis dan aktivitas siswa pada siklus 2 sesuai ddengan indiktor pada siklus I peserta didik di kelas VI SD Negeri No. 101/II Muara Bungo Kec. Pasar Muara Bungo Kab. Bungo.

Tabel 2. Lembar Observasi Aktivitas Siswa dan Hasil Belajar Siswa Pada Siklus II

\begin{tabular}{c|l|c|c}
\hline No. & \multicolumn{1}{|c|}{ Nama siswa } & Aktivitas Siswa & Hasil Pengerjaan Siswa \\
\hline 1 & AHMAD AFANDI & 12 & 15 \\
\hline 2 & AYU MARLINDA & 12 & 15 \\
\hline 3 & FITRA BAYU KRISTANTO & 11 & 15 \\
\hline 4 & JULIO PRASETYO & 9 & 15 \\
\hline 5 & KELVIN RENOL PERMANA & 8 & 15 \\
\hline
\end{tabular}




\begin{tabular}{c|l|c|c}
\hline No. & \multicolumn{1}{|c|}{ Nama siswa } & Aktivitas Siswa & Hasil Pengerjaan Siswa \\
\hline 6 & LUH DHENOK BANUWATI & 11 & 15 \\
\hline 7 & LUSI OKTAVIANI WENNO & 9 & 15 \\
\hline 8 & MUHAMMAD TIO SALSA WIJAYA & 9 & 15 \\
\hline 9 & MOHAMMAD ANGGAPRASETYO & 11 & 15 \\
\hline 10 & RIMA QORIA WATI & 10 & 12 \\
\hline 11 & RILA SUNDARI & 8 & 13 \\
\hline 12 & RIZKY SADONA AGISSIASAPUTRA & 10 & 13 \\
\hline 13 & RIZKY SANTOSO & 9 & 10 \\
\hline 14 & SANTI PRASTIWI & 6 & 18 \\
\hline 15 & TRY NURJANAH & 12 & 15 \\
\hline 16 & WIDYANOVITANIA SANDRA DEFNI & 10 & 15 \\
\hline 17 & WAHYU SETIAWAN & 7 & 15 \\
\hline 18 & MUHAMAD MANSUR MAULANA & 6 & 15 \\
\hline 19 & RIZKI ANTIKA NINGRUM & 10 & 15 \\
\hline 20 & FADILAH SARASUNI & 8 & 15 \\
\hline 21 & ALVIOLA DWI ARIFIN & 12 & 15 \\
\hline 22 & MEYSI RATNA INDARTI & 8 & 15 \\
\hline 23 & ANDRE JUNAIDY P & 8 & 15 \\
\hline 24 & LEVIA TAMYIZ & 6 & 15 \\
\hline 25 & SYAIFANI AMALIA & 10 & 15 \\
\hline 26 & YOKEBETH ALFA GEOFANI M & 6 & \\
\hline 27 & NUR ALDI FIRAMANSYAH & 10 & 15 \\
\hline 28 & ARDIYANSAH & & \\
\hline & & 10 & \\
\hline
\end{tabular}

Berdasarkah hasil observasi peneliti, pada siklus 2 diketahui para peserta didik kelas VI ralitif cukup baik dalam melaksanakan tugas yang diberikan oleh peneliti, meskipun ada sebagian yang masih bingung dalam mengerjakannya. Hal ini terlihat pada data yang termuat dalam lembar observasi di atas, yaitu 13 peserta didik yang cukup baik dalam melaksanakan tugas, yang artinya $46 \%$ baik dari seluruh peserta didik di kelas VI.

Berdasarkan analisi hasil pengerjaan tugas, hanya satu peserta didik yang mendapat penilaian sedang, itu artinya sudah 90\% para peserta didik di kelas VI SD Negeri No. 101/II Muara Bungo Kec. Pasar Muara Bungo Kab. Bungo sudah mampu membuat satu bait puisi sederhana.

\section{KESIMPULAN DAN SARAN}

Dari hasil penelitian tindakan kelas yang telah dilakukan terhadap para peserta didik di kelas VI SD Negeri No. 101/II Muara Bungo, dapat ditarik kesimpulan bahwa (1) Pada dasarnya para peserta didik kelas VI mampu untuk 
membuat suatu puisi sederhana, hanya saja diperlukan media yang dapat merangsang imajinasi mereka. (2) Media gambar ternyat dapat digunakan untuk merangsang imajinasi para peserta didik kelas VI, sehingga pada akhirnya mereka dapat membuat satu bait puisi.

Hasil penelitian ini di harapkan dapat memberikan sumbangan pemikiran dalam upaya meningkatkan mutu proses pembelajaran menulis. Adapun saransaran sebagai berikut: (1) Gunakanlah media pembelajaran yang tepat agar para peserta didik lebih mudah dalam menerima pembelajaran yang diberikan oleh guru. (2) Perbanyaklah membaca dan mencoba bagi guru, agar mampu membuat media pembelajaran lebih banyak, sehingga lebih mudah dalam menstraferkan ilmu kepada para peserta didik.

\section{DAFTAR PUSTAKA}

Ardana, Wayan. 1980. Beberapa Metode Statistik untuk Keperlian Penelitian Pendidikan. Malang : Swadaya.

Margono. 1997. Metodologi Penelitian Pendidikan. Jakarta : PT. Rineka Cipta

Soekamto, Toeti. 1997. Teori Belajar dan Model-model Pembelajaran. Jakarta : PAU-PPAI, Universitas Terbuka.

Soeratno dan Arsyat, Lincolin. 1988. Metodologi Penelitian untuk Ekonomi dan Bisnis. Yogyakarta : BPFE.

Sudjana, Nana. 1984. Dasar-dasar Proses Belajar Mengajar. Bandung : Sinar BaruAlgensido.

Syaiful, Bachri. 2000. Guru dan Anak Didik dalam Berinteraksi Edukatif. Jakarta : PT Rineka Cipta

Usman, Moh. Uzer. 2001. Menjadi Guru Profesional. Bandung : PT Remaja Rosdakarya. 